\title{
Reinventing and Promoting Northern Industrial Heritage: Regeneration in the Textile Sites of Ancoats and Saltaire
}

Réinventer et promouvoir l'héritage industriel du Nord de l'Angleterre: La reconversion des sites de l'industrie textile d'Ancoats et de Saltaire

\section{Aurore Caignet}

\section{(2) OpenEdition}

\section{Journals}

Electronic version

URL: http://journals.openedition.org/rfcb/5401

DOI: $10.4000 /$ rfcb.5401

ISSN: 2429-4373

\section{Publisher}

CRECIB - Centre de recherche et d'études en civilisation britannique

\section{Electronic reference}

Aurore Caignet, « Reinventing and Promoting Northern Industrial Heritage: Regeneration in the Textile Sites of Ancoats and Saltaire », Revue Française de Civilisation Britannique [Online], XXV-2 | 2020, Online since 25 May 2020, connection on 10 December 2020. URL : http://journals.openedition.org/rfcb/ 5401 ; DOI : https://doi.org/10.4000/rfcb.5401

This text was automatically generated on 10 December 2020.

\section{c) (i) $९$}

Revue française de civilisation britannique est mis à disposition selon les termes de la licence Creative Commons Attribution - Pas d'Utilisation Commerciale - Pas de Modification 4.0 International. 


\title{
Reinventing and Promoting Northern Industrial Heritage: Regeneration in the Textile Sites of Ancoats and Saltaire
}

\author{
Réinventer et promouvoir l'héritage industriel du Nord de l'Angleterre: La \\ reconversion des sites de l'industrie textile d'Ancoats et de Saltaire
}

Aurore Caignet

\section{Introduction}

1 This article seeks to explore and compare

the promotion of heritage and culture-led regeneration in the conservation areas of Ancoats and Saltaire, which lie outside the city centres of Manchester and Bradford respectively. Ancoats and Saltaire have an exceptional collection of buildings which are representative of the powerful and innovative textile industry of Manchester and Bradford: whilst the former was the world leader of the cotton industry - hence the nickname "Cottonopolis" - the latter was referred to as "Wool

City". 1

In July 1989, a 50-acre conservation area was designated in Ancoats, that is, almost two decades after Saltaire. ${ }^{2} \mathrm{~A}$ conservationareacan be defined as an area "ofspecial architecturalorhistoric interest, the characterorappearanceof which it isdesirabletopreserveorenhance"; 3

any new development or the demolition of existing buildings must comply with heritage conservation regulations and get the consent of the local planning authorities. ${ }^{4}$ Despite this official - albeit late - recognition of the historic significance of Ancoats as the world's first industrial suburb, ${ }^{5}$ 
in the early 1990s, Ancoats was one of Manchester's “undervalued peripheral areas

" where it was nonetheless possible to find "

cohesive sections of Manchester's archaeological and architectural heritage". ${ }^{6}$

Yet, some of the remaining industrial buildings were in a state of dereliction due to a

lack of maintenance and acts of vandalism, whilst others had to be pulled down

following arson attacks.

${ }^{7}$ The demolition of old industrial buildings was carried out "

in a piecemeal and unplanned fashion",

hence the loss of parts of Ancoats' industrial landscape. In comparison, Saltaire's industrial landscape has been well preserved despite deindustrialisation,

for it was built later than Ancoats and textile production only ceased in the mid-1980s, and also because it was recognised as heritage and protected accordingly before Salts

Mill had to close its doors.

We shall highlight the valuable role played by culture and heritage in the regeneration of the historic built environment, particularly that of industrial vestiges, and how both urban regeneration and industrial heritage are depicted in the local press, visitor guides, policy documents as well as official websites dedicated to tourism. Regeneration is understood as a process aiming at the positive transformation of a place that bears the marks of decline,

10

such as a deindustrialised area which needs to be redeveloped; it often refers to urban revitalisation following a period of "de -generation". ${ }^{11}$

It relies on different strategies that can be combined, including the restoration and reuse of historic buildings and the introduction of new ones, such as in Ancoats ${ }^{12}$,

in order to enhance an area. Our focus will be on industrial heritage in relation to the revitalisation of deindustrialised places as well as on

the promotional strategies that are used to sell the conservation areas of Ancoats and Saltaire to visitors, future residents or investors. It will be essential to look at initiatives resorting to culture and heritage as tools for the reuse and renaissance of historic buildings in deindustrialised areas seeking to enhance their image. Cultural activity can be “ the catalyst and engine of regeneration" ${ }^{\prime 13}$

, such as when it generates interest in neglected historic buildings and participates in their reinvention by investing them with new meanings and giving them a new function in line with contemporary needs. Moreover, as a form of tangible culture, industrial buildings can be considered as cultural heritage: “

heritage is a part of culture [...], but it also supports and transmits culture [...]". ${ }^{14}$

This article thus deals with a tangible heritage which is subjected to a conservation process - because it has been given value and constructed as heritage - and which can help maintain a sense of place in relation to the past in the present. 
I will examine the reinvention of Salts Mill in Saltaire, a model village within Bradford's metropolitan district, West Yorkshire. In 2001, Saltaire became a

UNESCO World Heritage Site, which corresponds to an area of approximately 20 hectares covering the size of the land its founder Sir Titus Salt had initially purchased. ${ }^{16}$

Salt's goal was to move his textile production to a rural setting on the outskirts of Bradford, where public buildings and workers' housing could be built next to integrated mills and form a homogeneous architectural whole

17

. Saltaire's development started with the completion of Salts Mill in 1853 and the subsequent construction of New Mill, which were built on opposite sides of the Leeds and Liverpool canal

${ }^{18}$.Salts Mill's cultural reuse and the "heritagization"19 of Saltaire from the end of the 1980s onwards will be counterbalanced by the examination of more ambivalent attitudes towards heritage and its role in the regeneration of Ancoats. Whilst Saltaire is characterised by a formal gridiron layout and architectural uniformity, Ancoats developed in a more disorganised fashion around the mills; it is a palimpsest of architectural styles also reflecting evolutions in functions. Ancoats' concentration of urban steam-driven mills constituted “ the first industrial landscape based on steam-power". ${ }^{20}$ Symbolising "theurbanisation of the factory system", ${ }^{21}$ the transformation of rural Ancoats into a" space of industrial production created by and for industry"22 started towards the end of the $18^{\text {th }}$

century with the construction of the Rochdale canal, textile mills, housing, churches, pubs, schools as well as premises for hat making and glassworks. ${ }^{23} \mathrm{After}$ decades of deindustrialisation in the $20^{\text {th }}$ century, Ancoats became largely forgotten . In 1993, industrial archaeologist Steve Little declared: “

Ancoats remains on the margins of Manchester's consciousness. Indeed, even historians dealing with the city have generally neglected Ancoats

". ${ }^{24}$ It became an "urban renewal area" as part of Manchester City Council's 1998 Unitary Development Plan for the City, ${ }^{25}$

a decision which might have been influenced by the setting up of Urban Regeneration Companies and Regional Development Agencies - such as the North West Development Agency - following the election of a Labour government in 1997.

26

This article will explore planning and promotional documents about Ancoats which oscillate between the acknowledgment of past glories and the will to move forward. If increasing interest has been directed towards the protection and reinvention of the

listed historic buildings

27

of Ancoats, they are mainly promoted for the revitalising potentialities of adaptive reuse. 
After shedding light on the role of industrial heritage in the regeneration of Saltaire

and Ancoats, and on

shifting perceptions towards the industrial past,this article will examine

the image of two northern post-industrial cities, Manchester and Bradford, in relation to tourism, through their promotional discourse.

\section{The role of industrial heritage in Saltaire's culture-led reinvention}

2015 was a crucial year for industrial heritage since as it was designated by the Council

European Industrial and Technical Heritage Year

of Europe as the "

", thereby demonstrating a lasting interest towards industrial heritage. InOctober 2015, the first ever World Heritage UK Conference was held in Saltaire, ${ }^{28}$

which is often cited as an example of Victorian philanthropic paternalism ${ }^{29}$

and which might have influenced other industrial settlements

. Yet, only thirty years ago, the future of

Saltaire's main mill was uncertain. According to a local journalist, Saltaire seemed to be

ghost village" ${ }^{130}$

$a^{\prime \prime}$

in the early 1980s, when the demise of industry was becoming inevitable. The local

community and authorities had to start thinking about an alternative economy.

According to Kenneth Powell, a British architecture critic and a campaigner of SAVE

${ }^{31}$ Salts Mill was to be considered as “

Britain's Heritage,

the centerpiece - indeed the raison d'être - of Sir Titus Salt's world famous model village". ${ }^{32}$

Not only was it the defining feature of Saltaire's identity, but it was also one of

Bradford's industrial - and architectural - gems (see ill.1).

In spite of its significance, there were no definite redevelopment plans $^{33}$

when Salts Mill ceased its production in February 1986, ${ }^{34}$

after over 130 consecutive years of industrial activity. The general mood was tainted with pessimism. Experts in architectural heritage and conservationists made alarming comments, as a statement found in a report by SAVE Britain's Heritage suggests: “

[...] the future of Salts Mill looks bleak, and the prospect of its standing empty at the heart of the ".35 village is horrifying

There were already redundant mills all over the country which were becoming derelict and facing demolition: in 1983, West Yorkshire had over 10 million square feet of vacant industrial space.

36

Not every single industrial building could be saved, and those that remained standing would have to be given a new relevant purpose in order to survive.

Illustration 1:Salts Mill, Saltaire 
Source: Aurore Caignet, 10 November 2015.

Two months after closing its doors, the future of Salts Mill was discussed amongst experts in the field of industrial heritage and conservation who stressed its exceptional architectural and historical significance.

${ }^{37}$ There were talks of turning the mill into a museum, ${ }^{38}$ as it was hoped a cultural conversion might catalyse the revitalisation of Saltaire. The potential transfer of the National Indian Collection of ethnic art from the Victoria \& Albert Museum to Salts Mill

was one of several projects discussed to give it a viable role that would also induce a heritage-led conversion. As Powell argued, “ [...] new museums are symbols of regional and national pride and often provide a focus for the $" .40$ revival of whole areas

However, the re-use of the mill as a museum - whether it was to be dedicated to industry in general or to textile in particular - would have been another example of what Kevin Walsh calls “ the heritagization of space", ${ }^{41}$

that is, the instrumental use of heritage as a resource and a commodity, which can lead to the dilution of the heritage product. Plans to convert Salts Mill into a museum were eventually abandoned: it proved to be a safe move, especially when considering the number of museums across England which were already wholly or partly dedicated to industry. 
If Saltaire is the result of an industrialist's comprehensive vision, the rebirth of Salts Mill in 1987 is attributable to another visionary called Jonathan Silver. The local entrepreneur who bought the mill embarked on a journey of cultural and heritage-led regeneration, which helped kick-start the revival of the Saltaire conservation area, which was designated in 1971. For example, New Mill, which was built between the River Aire and the canal, just opposite Salts Mill, was given a new lease of life in 1992: offices were created for Bradford's Health Authority whilst other parts of the building were converted into luxury apartments.

${ }^{43}$ This regeneration came about after a period of neglect, when New Mill was a “

derelict shell" ${ }^{\prime 4}$

and shops and food outlets on Victoria Road - Saltaire's commercial artery - were closing down. And since the reopening of Salts Mill, as well as the World Heritage Site designation in 2001, virtually all the buildings within the conservation area - such as the mills, shops, workers' homes, and hospital - have been in use.

Instead of dwelling on Salts Mill's past, Silver chose to renew its purpose by inserting contemporary art into this former space of industrial production, which became a place of cultural consumption. The mill would thus have the potential to attract a larger audience than if it had been converted into an industrial museum. However, the original layout of the mill was preserved as much as possible as its vast open space was particularly suited to the opening of an art gallery, which has been exhibiting the works of Bradford-born artist David Hockney since 1987. His reputation has helped the mill gain visibility: an article from The Guardianeven went as far as to call it a "cultural emporium". ${ }^{45}$

Yet, Silver did not take a leap of faith as such, as he had already taken part, alongside with Sir Ernest Hall, in the conservation and adaptive re-use of Dean Clough Mills in Halifax, West Yorkshire. In an

English Heritage Conservation Bulletin, both conversions were praised for being “[...] among the first sets of buildings to demonstrate how the determination of visionary individuals could transform negative perceptions of the industrial past ".46

This is not to say that industrial heritage is systematically perceived in a more positive way once it changes function, or that once an industrial building is re-used, its industrial past can still be read by new users and its industrial character be universally appreciated. Casella and Symonds contend that there still exists “ a prevalent perception that industrial heritage is backward looking, whilst regeneration is forward looking $"{ }^{47}$

Yet, in the case of Salts Mill, despite its stately appearance, one can hardly fail to identify it as a former textile factory, and anyone visiting the mill and Saltaire is bound to realise that industrial heritage and regeneration are not incompatible, even if conflicts may occur. The artworks adorning the walls of the building also play a part in altering the public perception of this industrial space, the latter being seen in a new light (see ill.2). In the 1990s, Salts Mill would benefit from multiple positive reassessments thanks to its 12 successful cultural reinvention. An article published in the

Telegraph and Argus 
, a local newspaper, offers a retrospective vision of the mill and its environment as it was in the 1980s, describing them as " an uninhabited shell at the foot of a quaint but slightly shabby village" 48

before shedding light on its art-led renaissance, which is evocatively suggested in the

title: “

How the arts can give city a kick up the pants

". It is as if a clear-cut dichotomy between past and present was created - and exaggerated, perhaps - by giving a depressing picture of Saltaire to Salts Mill's cultural makeover, so as to accentuate the idea of a renaissance. This article gives the impression that the successful cultural reuse of this centerpiece of industrial heritage played a role in the resurrection both of the building and of the whole area. However, Salts Mill is more likely to be associated with its current function rather than with its industrial past since the new artistic content of the building is foregrounded at the expense of its historical and architectural value.

\section{Illustration 2:The 1853 Gallery, Salts Mill, Saltaire}

Source: Aurore Caignet, 10 November 2015.

One may wonder whether Saltaire is more famous now for its industrial past or for its connection with Hockney, as corroborated by the European Route of Industrial

$", 49$

which implies that Saltaire owes its status to Hockney's representation, without which it might not have become renowned. It ends with the following statements: “ The largest attraction is an exhibition of the work of David Hockney. In 2001 Saltaire Village was inscribed into the United Nations list of World Cultural Heritage sites. 
In addition to the fact that the juxtaposition is odd, it is also misleading: it seems to suggest that the UNESCO label was attributed as a result of the permanent art exhibition held at Salts Mill. If this inscription was an acknowledgment of the

successful revitalisation of Saltaire and its mill and if it aimed at promoting the outstanding conservation of industrial heritage, the latter is nonetheless overshadowed by a cultural conversion mostly dedicated to art.

Salts Mill's cultural rebirth corroborates the idea that "

industrial production sites in the western world have acquired a new aura as they have been incorporated into art and popular culture $" .51$

Not only is it used by the city of Bradford as a promotional tool to highlight a city-wide

${ }^{52}$ but Jonathan Silver's "philosophy of regeneration through the arts" ${ }^{3}$ regeneration, also appears to have been instrumental in the increasingly positive perception of the mill by residents, visitors and investors. Indeed, an article from Telegraph Weekend Magazineabout Silver and the mill used the pun "mills and boom" 54 for its title, signalling a departure from the traditional association between mills and decline. Far from putting Salts Mill on a par with “ satanic mills" ${ }^{\prime 5}$

, an article published in a local magazine in 2008 compares it to the pyramids of Egypt. ${ }^{56}$ This slightly hyperbolical statement hints at the fact that the regeneration of the mill has generated civic pride, mainly as a result of its heritagisation.

In many ways, Hockney's playful painting of Saltaire, which was painted in 1997 as a 57 tribute to Salts Mill's late owner Jonathan Silver,

confirmed a radical departure from previous negative depictions of industrial landscapes and industrial scenes in general. His highly colourful representation of Saltaire's industrial landscape breaks away from derogatory clichés about grim and derelict Northern industrial cities. These had been circulating with the start of the deindustrialisation process in the post-war years and in response to its calamitous effects in the last decades of the twentieth century. In the late 1990s - ten years after its rebirth - Salts Mill and its model village were already starting to illustrate the benefits of regenerating industrial heritage by using culture as a tool to transform, without reinventing ex nihilo

, the image of a post-industrial area. Yet, if the regeneration process in Saltaire was respectful of the historic environment and sought to shed light on industrial heritage, the emphasis on Salts Mill's cultural reuse and its contribution towards the shaping of a positive image prevails over the cultural heritage of the industrial past and its numerous physical inscriptions in Saltaire. 


\section{Revaluing and reusing industrial buildings: the regeneration of Ancoats, Manchester}

The ongoing regeneration of the conservation area of Ancoats has been slow and limited to a number of listed buildings. Whilst the Daily Express Building

- a 1930s art deco building housing print works and offices - was listed by English

Heritage in 1974,

59

the pioneering cotton spinning mills of Ancoats were only considered for listing two decades later. It was property speculation rather than their historic value which would later attract attention. Manchester's

bid for the 2000

Olympics resulted in speculators buying some of the mills, which were left empty and started to quickly deteriorate once the bid failed.

${ }^{60}$ Although in 1999 Ancoats was described in a Mancunian newspaper as “

a little time-warp waiting to be discovered", ${ }^{61}$

four years later, another article referred to its cotton mills as empty "brick carcasses" 62 waiting to be brought back to life.W

hen conservations measures were implemented and regeneration schemes started to materialise, the poor appearance of Ancoats, with derelict buildings seen as eyesores, kept putting people off from living, working and investing in the area.

Therefore,

regeneration was impeded by the area's uninviting appearance and, most importantly, by the fact that there were multiple private owners until the acquisition by the North West Development Agency (NWDA) of some of the land and buildings thanks to a Compulsory Purchase Order undertaken in September 2002.

63

Urban regeneration agencies set up to plan the revival of Ancoats from the 1990s onwards continued to collaborate with preservation bodies concerned with conservation issues in relation to the preservation of Ancoats' urban industrial character. Industrial archaeologists were involved in conservation-led regeneration strategies, in Heritage Lottery bids, and in safeguarding what remained of the industrial heritage of Ancoats for posterity

(ill.3).

Unforeseen circumstances in connection with the 2008 economic crisis slowed down the regeneration process as the residential conversion of Grade II* listed Murrays' Mills following their restoration had to be put on hold for several years. However, the election of the Coalition government in 2010 coincided with the expiration of area-based regeneration programmes,

65

which had an impact on the level of funding dedicated to the restoration and redevelopment of historic buildings in Ancoats.

Illustration 3: Textile mills in Ancoats 
Source: Aurore Caignet, 25 October 2015.

It does not mean that the regeneration process suddenly came to a halt, as the

on the UK tentative list for World Heritage status in 1999 had previously highlighted its universal significance as the first industrial suburb.

67

It had thus contributed to putting Ancoats back on the heritage map and to attracting renewed interest. Interestingly, the bid was subsequently withdrawn, a move which could have been linked to suspicions towards regulations imposed by UNESCO in regards to future developments.

${ }^{68}$ According to Lyn Fenton, former head of the Ancoats Urban Village Company ${ }^{69}$

(AUVC was responsible for the regeneration of Ancoats), it could have impeded the regeneration of the conservation area and the wider historic area.

70

For example, the New Islington development facing the group of preserved mills would have been much more scrutinised. However, fewer restrictions can also lead to a greater focus on new architectural inscriptions rather than on the historic environment, regardless of the detrimental effects they may have on the conservation of an industrial character and on the development of heritage tourism within the conservation area.

A forward-looking stance stems from the NWDA's 2008Annual Review

of Ancoats, which provides an overview of the degree of regeneration achieved. This document puts to the fore the transformation of " Manchester's proud industrial heritage into a vibrant commercial future", ${ }^{71}$ a perfect " business location" with “ 
stylish premises that combine rich historic character with a contemporary feel and modern, urban vitality $" .^{72}$

Former industrial buildings were therefore revalued for their re-use potential allowing them to become desirable office and residential spaces characterised by an "authentic"

historic aura. In this respect, Rosemary Mellor argues that " [...] the accreditation of the artifacts of the city's past with value was a total reversal of the previous policy of demolishing 'Cottonopolis'.

Whilst being, in some ways, respectful of the industrial past, the regeneration of Ancoats is future-oriented, and its main concern lies in making the district an extension to Manchester city centre and especially the culturally vibrant Northern Quarter. The planning guidance published in 1999 made clear that Ancoats should move forward and “

become more than a monument to its past", ${ }^{74}$

without altogether shunning its industrial heritage, even though the role of industrial heritage in urban renewal has been limited to the reuse of a handful of significant

historic buildings as a means of highlighting the area's idiosyncratic identity. Nevertheless, the restoration and reuse of industrial vestiges such as Murrays' Mills and the Ice Plant Building

- formerly used as an ice-storage warehouse - showed how conservation-led regeneration could be achieved so that heritage assets get to make a positive and substantial contribution towards the reinvention of a historic district, even if the final outcome consists of securing future local investments and attracting residents and businesses rather than giving visibility to industrial heritage perse.

The fact that regeneration initiatives incorporate industrial heritage by rejuvenating and converting industrial vestiges indicates an increasing recognition of the value of this heritage - be it historical, cultural, architectural - and demonstrates the sense of place these buildings can help to convey. Although the demolition of industrial vestiges still occurs, the potentialities of industrial heritage tend to be taken into account when regenerating post-industrial areas. The NWDA considers historic buildings, including industrial ones, as " assets that, in addition to their intrinsic merit can, in the majority of cases, contribute to the vitality and economic life of the surrounding area

$\eta_{76}$

once they are put to new uses. If conservation-led regeneration schemes are encouraged for what can be gained from them economically speaking, such discourse also highlights a fundamental change in the way the industrial built environment is perceived. The fourth Annual Review about the progress of regeneration in Ancoats claims that it celebrates its industrial heritage.

Illustration 4: Public Art in Cutting Room Square, Ancoats 
Source:Aurore Caignet, 26 September 2016.

If the promotion of heritage in Ancoats is often linked to residential and commercial conversions, efforts have been made to incorporate culture into several revitalising projects. For example, a “ cultural masterplanner

" was appointed to remake the public realm by providing urban art that combines old and new and reminds one of Manchester's spirit of innovation.

78

Artist Dan Dubowitz created spy-holes inserted in exterior walls of several buildings all around Ancoats, in order to reveal historic walled-up objects, whilst five contemporary commemorative sculptures were set up on the main public square, displaying evocative ${ }^{79}(\mathbf{i l l . 4})$ Moreover, cultural and creative industries ${ }^{80}$ photographs of the once derelict area. have progressively relocated to some of the mills. The conversion of Beehive Mill was seen in the mid-1990s as the first step towards the renaissance of Ancoats. The cultural reuse of this Grade II* listed cotton mill built in 1824 took place in 1996 , 81 resulting in the creation of workspace accommodation, music rehearsal studios, as well as a renowned nightclub based on the ground floor. 82

According to an article published inMCR Magazinein 2010, “

[a]s Manchester became invigorated by other pursuits, namely music and pop culture, [...] its post-industrial landscape offered a breeding ground for artists looking for escapism. The Beehive $" .83$ 
As mills are given a new purpose and as their value is reassessed, their industrial and "edgy" character makes them ideal spaces for the expression and celebration of a fertile Northern culture. Recycling industrial buildings through culture also participates in the reshaping of the image of the industrial fabric as much as it is likely

to modify new users' perceptions towards the presence of former factories and warehouses in the cityscape. Even though negative stereotypes about Ancoats still need to be tackled, the industrial built environment is regarded more as an asset than as a liability, as “

an opportunity, not simply a disaster." 84

Reshaping the image of northern post-industrial cities: promoting the city as a tourist destination

If heritage and culture-led regeneration can help post-industrial cities attract new residents and businesses by transforming deindustrialised areas and encouraging the reclaiming of former industrial spaces by the creative industries for instance, they can also rely on these processes to enhance their image and develop tourism. Yet, industrial heritage is not systematically included in the city's image, nor does it necessarily play a significant role in tourism promotion. In this regard,

industrial heritage is less prominent in Manchester's image and tourism promotion than in Bradford's.

The goal of AUVC was to turn Ancoats into an urban village “ that would attract and welcome visitors as opposed to a tourist attraction". ${ }^{85}$

Back in the early 1990s, Manchester's Conservation Areas and Historic Buildings Panel was against the " museumification" 86 of the historic fabric as it believed that Ancoats "could be promoted as a development area on the back of its wealth of assets". ${ }^{87}$

The regeneration of Ancoats relied on the residential and commercial re-use of industrial buildings - whilst culture-led conversions remained an exception - rather than on a tourist-oriented redevelopment. Moreover, the slogan for Ancoats Urban Village was “

live, work and play" ${ }^{88}$ or "live, work and visit", ${ }^{89}$

which suggests an order of priority implying that it was not to be promoted primarily as a destination for industrial heritage tourism. Indeed, Ancoats remains mostly absent from the tourist map: it is excluded from maps inserted in many visitor guides published between 2000 and 2010, even though, interestingly, it is mentioned in the (ill.5) latest official leaflet advertising guided walks in Manchester.

Illustration 5: “Live, Work, Visit”, Jersey Street, Ancoats 
Source:Aurore Caignet, 25 October 2015.

As suggested by industrial archaeologists Casella and Symonds, “

[...] Manchester is being transformed by regeneration, shaking off many of the negative connotations associated with factory-based industrial production, and remaking itself as a 21 ${ }^{\text {st }}$ century city [...]". ${ }^{90}$ The promotion of

a new cosmopolitan and vibrant city image is alluded to on the website for Visit Manchester, the tourist board for Greater Manchester.

${ }^{91}$ Its main objective is "

to attract visitors to the destination through the effective promotion of Greater Manchester as both a leisure and business destination

$" .{ }^{92}$ Although Ancoats featured as the first industrial heritage attraction in January 2016

${ }^{93}$ on the page dedicated to "the best of Visit Manchester's top 5 guides

", industrial heritage attractions only come 13 out of a list of 15 guides, far behind guides advertising restaurants, pubs, music venues, nightclubs, and so on.

According to the "what to do" page, favourite activities include: drinking, eating, shopping, theatre-going and museum visiting.

95

The promotion of tourism in Manchester capitalizes less on industrial heritage than on entertainment, nightlife, sporting events, shopping or the arts.

However, efforts were made in the past in order to promote the industrial heritage of the Northwest in general, thanks to marketing campaigns - “

Industrial Powerhouse" was created in 2004, followed by "Modern History

" in 2010 - which led to print advertisement inMCR Magazine

. In 2008, one advertisement displayed the catchphrase “

over 230 years of industrial history on your doorstep: discover Manchester, the revolutionary heart of England's northwest 
alongside with an image of a man dressed in attire hinting at the past and the present.

This advert thus seems to focus on people rather than on the historic environment 97

and promotes a dynamic and personal experience of history, yet it is not visually compelling and fails to highlight what there is to do and see in the city which pertains to its industrial past. Similarly, none of the city's industrial vestiges were visually represented in the double pages promoting industrial heritage in the same magazine: the illustrations do not represent Manchester per se, but industrial vestiges found in the region..$^{98}$ The same could be said about another "Industrial Powerhouse" advert found in MCR Magazinein 2010:"99if this "collage-style advertisement"

offers a visual summary of industrial heritage in the North West of England, Liverpool's architectural fabric is given centre stage. The incorporation of two factory chimneys and a mill might hint at Manchester's textile heritage, but their anonymity allows them to stand for any of the region's former industrial towns.

In contrast to Manchester, Bradford decided to build upon its most remarkable industrial vestiges - including Saltaire - as early as 1980, hoping it would succeed in enhancing its image and in attracting visitors. Indeed, it was arguably the first postindustrial city in Britain to use industrial heritage for tourism purposes.

The marketing section of Bradford's Economic Development Unit would regularly advertise industrial heritage weekend breaks 102

featuring industrial sites, including Saltaire and Salts Mill. Maria Glot, Bradford's first appointed Tourism Officer, admitted that the task was a difficult one: “

We said Bradford was on the holiday market and everybody was laughing, because Bradford was seen as a backwards northern industrial town where even the pigeons fly backwards to keep the soot out of their eyes ${ }^{\prime 103}$

Against all odds, industrial heritage sites like Saltaire are still used to sell Bradford as a tourist destination, and they get to play a positive role in the redefinition of Bradford's

image.

Far from turning its back on its industrial legacy, Bradford has embraced it: the year Saltaire became a World Heritage Site, Bradford's conference guide gave prominence to representations of Salts Mill on the cover and inside the brochure.

104

In 2016, depictions of Saltaire's industrial buildings also appeared on the cover of Bradford and District Visitor Guide and in four inside pages.

105

Despite the persistence of negative perceptions of Bradford in relation to the demise of the textile industry, the city has been partly relying on industrial heritage sites to try and distinguish itself from other urban tourist destinations. Whilst Saltaire has become one of Bradford's main attractions - due to its UNESCO affiliation - the development of tourism in the former industrial village seems to have been instrumental in its longterm regeneration. 


\section{Conclusion}

Bradford seems to capitalise on its industrial heritage - and therefore on Saltaire - in order to sell itself as a tourist destination,

the development of heritage tourism is far from being a priority

in Manchester. Ancoats remains largely

off the beaten track despite efforts to make it more attractive

, and the revitalisation of its industrial vestiges

mainly revolves around their residential, commercial and, to a lesser extent, cultural reuse. However, given its proximity to the city centre, Ancoats could be on the verge of becoming Manchester's new Northern Quarter, as it is being turned into an "edgy" urban district prone to attract a creative population looking to live, work and play in spaces with an industrial character. In this respect, Bradford and Manchester have come to recognise the instrumental role that the reinvention and promotion of historically significant industrial vestiges can play in kick-starting the regeneration and the re-imaging of a deindustrialised area. This, in turn, helps attract positive attention by shifting perceptions, especially when this regeneration incorporates a certain level of cultural activity and provides access to art, the latter being suited to the enhancement of an area and the celebration of its idiosyncratic identity, such as the Peeps in Ancoats.

Whether one considers Saltaire's lasting rebirth - which results primarily from Salts Mill's cultural conversion, followed by its becoming a World Heritage Site - or the regeneration of Ancoats - which seeks to celebrate industrial heritage without preserving it in aspic - the conservation of industrial heritage is compatible with the permanence or the re-creation of a living community. Once given a new purpose, this

experienced on a daily basis instead of being simply visited, can serve to promote an image of northern industrial heritage as having its rightful place in 21

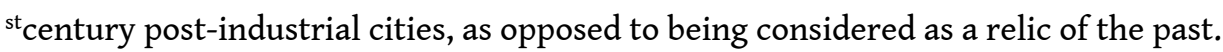

\section{BIBLIOGRAPHY}

Ancoats - An Archaeological Perspective

, Oxford Archaeology North, Ancoats Buildings Preservation Trust, Manchester Central Library: Special Collections, GB127.MISC/1281/2/2/5

Ancoats - History with a Future

, Ancoats Buildings Preservation Trust, Manchester Central Library: Special Collections,

GB127.MISC/1281/2/2/2 
Ancoats, Manchester Conservation Areas,

$\mathrm{n}^{\circ}$ 24, Manchester City Council Planning Department, 1991, Q363.69Ma(464)

Ancoats - the World's First Industrial Suburb,

leaflet, undated, Ancoats Buildings Preservation Trust, Manchester Central Library: Special

Collections, GB127.MISC/1281/2/2/4

Ancoats Annual Review, North West Development Agency, 2008-2009.

Ancoats Annual Review, North West Development Agency, 2009-2010.

Ancoats Peeps, <http://ancoatspeeps.com/?p=cultural-masterplanning>, [accessed 18 October 2018].

Ancoats Urban Village, Annual Report, North West Development Agency, 2007.

Ancoats Urban Village Heritage Lottery funding bid, Ancoats Building Preservation Trust, 1999, Manchester Central Library: Special Collections, q363.69An(172)

Annual Report 1993

, Manchester Conservation Areas and Historic Buildings Panel, Manchester Communication Services, 1993.

Auclair, Elizabethand Fairclouch, Graham (eds.),

Theory and Practice in Heritage and Sustainability: Between Past and Future

(New York, Routledge, 2015).

Best of Top 5

, Visit Manchester, <www.visitmanchester.com/articles/top-5s/best-of-top-5s/>, [accessed 25 January 2019].

Binney, Marcus, Fitzgerald, Ron, Langenbach, Randolph and Powell, Kenneth

, Satanic Mills: Industrial Architecture in the Pennines(London, SAVE Britain's Heritage, 1978).

Bluhm, Robin, "Manchester, the Great Victorian City",The Victorian

, n 8, November 2001, pp. 12-15.

Bradford Industrial Heritage Tour

, Bradford Economic Development Unit, City of Bradford Metropolitan Council, 1982.

Bradford's Yorkshire Heritage Breaks September 1982-April 1983

, Bradford Economic Development Unit, City of Bradford Metropolitan Council, 1982.

Bradford's Brontë Country Mini-Holidays

, January-December 1984, Bradford Economic Development Unit, City of Bradford Metropolitan

Council, 1984.

Bradford and District Visitor Guide 2016

, Visit Bradford, City of Bradford Metropolitan District Council, 2016.

Bradford Historical and Antiquarian Society,Crisis at Saltaire

, 1987, <http://www.bradfordhistorical.org.uk/saltaire.html>, [accessed 5 May 2019].

Butler, Paul, Finlay, Ian and Tye, David, “Ancoats Urban Village: old mills, new homes” in John Parkinson-Bailey (ed.),

Sites of the City, Manchester: Essays on Recent Buildings by their Architects

(Manchester, Manchester Metropolitan University, 1996), pp. 117-123.

Casella, Eleanor and Symonds, James (eds.),Industrial Archaeology: Future Directions(New York, Springer Science \& Business Media, 2005). 
Clark, Roger, “A Look into the Past: Why Saltaire Is on a Par with the Pyramids",ProsiderGuide (Shipley, Saltaire, Bradford, Prosider Media Publishing, 2008).

Conference Guide Bradford and District

, Department of Marketing and Communications, City of Bradford Metropolitan District Council, 2001, Shipley College: The Saltaire Collection Archive.

Crinson, Mark and Tyrer, Paul, "Clocking off in Ancoats: time and remembrance in the postindustrial city" ",

in Mark Crinson(ed.),Urban Memory: History and Amnesia in the Modern City

(London, Routledge, 2005), pp. 49-71.

Daily Express Building, A-Z of Listed Buildings in Manchester, <http://www.manchester.gov.uk/ info/514/listed_buildings_register/1908/a-z_of_listed_buildings_in_manchester/7>, [accessed 6

December 2018].

Debary, Octave, "Deindustrialisation and museumification: from exhibited memory to forgotten history", Annals of the American Academy of Political and Social Science, 595, 2004, pp. 122-133.

European Route of Industrial Heritage, <http://www.erih.net/i-want-to-go-there/site/show/ saltaire-village/>, [accessed 24 October 2018].

Evans, Graeme and Shaw, Phyllida,The Contribution of Culture to Regeneration in the UK, A Report to the DCMS, London Met, 2004.

Fenton, Lyn, interview by the author, 3 October 2016, Manchester.

Greenhalf, Jim, "Salt of the Arts: Two Top Yorkshire Artists Bring Exclusive Works to Bradford", Telegraph and Argus, 16 July 1993.

Greenhalf, Jim, "How The Arts Can Give City a Kick up the Pants",Telegraph and Argus, 1 June 1993. Glot, Maria, interview by the author, 13 October 2016, Saltaire.

Gold, John R., "Locating the message: place promotion as image communication", in John R. Gold and Stephen V. Ward (eds.),

Place Promotion: The Use of Publicity and Marketing to Sell Towns and Regions

(Chichester, Wiley, 1994), pp. 19-38.

Haile, Deborah, “Ancoats Hailed as 'New Castlefield”,,Manchester Evening News, 28 October 1999.

Heeley, John,Urban Destination Marketing in Contemporary Europe: Uniting Theory and Practice , (Bristol, Channel View Publications, 2015).

Heritage Lottery Fund,HLF Major Grants - The first 100 , June 2015, <https://www.heritagefund.org.uk/sites/default/files/media/research/ hlf_major_grants_-_the_first_100.pdf>, [accessed 23 March 2019].

Heritage Works, <http://www.heritageworks.co.uk/abpt-final/about_ancoats_buildings.htm>, [accessed 24 October 2018].

“Hockney Unveils Tribute to Mill Owner and Friend”,Yorkshire Post, 15 December 1997.

Lavender, Jane, "More than Cotton Mills and Canals",Metro, 15 August 2003.

Little, Steve, “Ancoats: Protecting the Unprotectable?",Manchester Region History Review 7 (1993), pp. 97-104.

Lynch, Kevin,What Time Is This Place?[1972] (Cambridge, Massachusetts: the M.I.T. Press, 2001). 
Macaskill, Hilary, “Local Hero, Local Colour”, The Guardian, 15 February 1996.

Madgin, Rebecca, "Making the most of our existing urban assets?

New Labour's focus on the historic urban environment", in Sylvie Nail and David Fee (eds.),

Vers une renaissance anglaise: dix ans de politique travailliste de la ville

(Paris, Presses Sorbonne Nouvelle, 2008), pp. 35-54.

Mcneil, Robina and George, David (eds.),

Manchester - Archetype City of the Industrial Revolution: A Proposed World Heritage Site

(Manchester, University of Manchester Field Archaeology Centre, 2002).

MCR Magazine, November 2008.

MCR Magazine, 6 May 2010.

Mellor, Rosemary, "Cool times for a changing city",inNick Jewson and Susanne Macgregor (eds.), Transforming Cities: Contested Governance and New Spatial Divisions

(London, Routledge, 1997), pp. 56-70.

Myers, Kathy, “End of a 133 Year Era at Salts Mill”,Telegraph and Argus, 10 August 1986.

Neaverson, Peter and Palmer, Marilyn,Industrial Archaeology: Principles and Practice

(London, Routledge, 1998).

Pendlebury, John, "Conservation of the historic environment", in Barry Cullingworth, Vincent Nadin, Trevor Hart, et al., Town and Country Planning in the UK(London, Routledge, [1964] 2015), pp. 317-350.

Planning (Listed Buildings and Conservation Areas) Act 1990, <https://www.legislation.gov.uk/ ukpga/1990/9/section/69> [accessed 24 October 2018]

Powell, Kenneth, “Phenomenal Monument at Risk: Crisis at Saltaire”,Country Life, 20 March 1986.

Powell, Kenneth, “Mill into Museum”,The Daily Telegraph, July 1987.

Priestley, Mike, “Saltaire”,Telegraph and Argus, 24 March 1990.

Rayner, Richard, “Mills and Boom”,Telegraph Weekend Magazine, 16 September 1989.

Regeneration Prospectus: To Further Economic Development and Regeneration

, North West Development Agency, March 2002.

Rodwell, Denis, “Heritage and development - Bridging the gap?", in Heike Oeverman and Harald

A. Mieg (eds.),

Industrial Heritage Sites in Transformation: Clash of Discourses(New York, Routledge, 2015), pp. 29-46.

Rose, Michael E., Falconer, Keith and Holder, Julian,Ancoats: Cradle of Industrialisation

(Swindon, English Heritage, 2011).

Saltaire, 2001, UNESCO World Heritage Centre Nomination Documentation, <

http://whc.unesco.org/uploads/nominations/1028.pdf.>,[accessed 18 January 2019].

Saving the Age of Industry, Conservation Bulletin, English Heritage, $\mathrm{n}^{\circ}$ 67, autumn 2011.

Smith, Laurajane,Uses of Heritage(New York, Routledge, 2006).

Smith, Melanie K.,"Towards a cultural planning approach to regeneration",in

Melanie K. Smith (ed.),Tourism, Culture and Regeneration(Wallingford, CABI, 2007),pp. 1-11.

Supplementary Planning Guidance - Ancoats Urban Village

, Manchester, Manchester City Council, 1999. 
Tallon, Andrew,Urban Regeneration in the UK[2010] (Abingdon, Routledge, 2013).

Thornton, Helen, « Saltaire's Role in Regeneration », 21 July 2014, <https:// www.academyofurbanism.org.uk/saltaires-role-in-regeneration/>, [accessed 13 October 2018].

Top 5 Industrial Heritage Attractions

, Visit Manchester, <www.visitmanchester.com/articles/top-5s/top-5-industrial-heritageattractions/>, [accessed 25 January 2019].

Visit Manchester Brief: Public Relations for Modern History

, Visit Manchester, September 2010, <http://www.marketingmanchester.com/media/31071/ brief\%20for\%20pr.doc.>, [accessed 2 May 2019].

Walsh, Kevin,The Representation of the Past: Museums and Heritage in the Post-Modern World (London, Routledge, 1992).

What to Do

, Visit Manchester, <www.visitmanchester.com/what-to-do/>, [accessed 25 January 2018].

Williams, Mike, “The Mills of Ancoats”,Manchester Region History Review7, 1993.

Willim, Robert, "Looking with new eyes at the old factory: on the rise of industrial cool",in Tom O'Dell and Peter Billing,Experiencescapes: Tourism, Culture and Economy

(Copenhagen, Copenhagen Business School Press DK, 2005), pp. 36-48.

Woods, Clive, "Emergency Seminar for Saltaire: Experts Fight to Save Mill”,Target , n 290, 3 April 1986.

World Heritage UK, <https://worldheritageuk.org/category/conference-saltaire-october-2015/>, [accessed 28 January 2019].

\section{NOTES}

1. Michael Hickling, "The Rise and Fall of Wool City", Yorkshire Post, 21 November 2007, <http:// www.yorkshirepost.co.uk/news/analysis/the-rise-and-fall-of-wool-city-1-2476782>, [accessed 29 April 2019].

2. It is bounded by Great Ancoats Street, Oldham Road, Wadeford Close, Jersey Street and the Rochdale Canal bordering a succession of cotton spinning mills, Robin Bluhm, "Manchester, the Great Victorian City", The Victorian, ${ }^{\circ} 8$ (November 2001), p. 13.

3. Planning (Listed Buildings and Conservation Areas) Act 1990, <https://www.legislation.gov.uk/ ukpga/1990/9/section/69> [accessed 24 October 2018].

4. Local planning authorities have been responsible for the designation of conservation areas since the creation of this system under the 1967 Civic Amenities Act, which underlined the necessity to protect historically significant areas, John Pendlebury, "Conservation of the historic environment", in Barry Cullingworth, Vincent Nadin, Trevor Hart, et al., Town and Country Planning in the UK (London, Routledge, [1964] 2015), p. 322.

5. Ancoats Urban Village Heritage Lottery funding bid, Ancoats Building Preservation Trust, 1999, Manchester Central Library: Special Collections, q363.69An(172); Ancoats - the World's First Industrial Suburb, leaflet, undated, Ancoats Buildings Preservation Trust, Manchester Central Library: Special Collections, GB127.MISC/1281/2/2/4

6. Annual Report 1993, Manchester Conservation Areas and Historic Buildings Panel, Manchester Communication Services, 1993, p. 4.

7. "[...] loss of the fabric of the area by fire, or unauthorized demolition, at an alarming rate", idem. 
8. "[...] this process of demolition, if continued in a piecemeal and unplanned fashion, will mean that the remaining fabric of this historic area must reach a point of no return", Steve Little, "Ancoats: Protecting the Unprotectable?", Manchester Region History Review, vol. 7 (1993), p. 103.

9. Despite the loss of $1 \%$ of the original buildings and the insertion of modern windows and doors on some houses, major buildings and groups of houses remain unaltered and were thus listed as buildings of special architectural or historic interest in 1985; Saltaire, UNESCO World Heritage Centre Nomination Documentation, 2001, <http://whc.unesco.org/uploads/nominations/ 1028.pdf.>, [accessed 18 January 2019, p. 26.

10. Graeme Evans and Phyllida Shaw, The Contribution of Culture to Regeneration in the UK, A Report to the DCMS (London Met, 2004), p. 4.

11. Melanie K. Smith, "Towards a cultural planning approach to regeneration", in Melanie K. Smith (ed.), Tourism, Culture and Regeneration (Wallingford, CABI, 2007), p. 1.

12. Ancoats, Manchester Conservation Areas, $n^{\circ} 24$, op. cit.

13. Graeme Evans and Phyllida Shaw, op. cit., p. 5.

14. Elizabeth Auclair and Graham Fairclough (eds.), Theory and Practice in Heritage and Sustainability: Between Past and Future (New York, Routledge, 2015), p. 3.

15. Laurajane Smith, Uses of Heritage (New York, Routledge, 2006), p. 3.

16. Saltaire, UNESCO World Heritage Centre Nomination Documentation, p. 1.

17. "in its unified architectural style, its construction quality and its building hierarchy, it exhibits midVictorian society's pre-eminence in European imperialist and technological domination, and the paternalistic, moral and practical philanthropy that was characteristic of that society.", Saltaire, UNESCO World Heritage Centre Nomination Documentation, p. 17.

18. Peter Neaverson and Marilyn Palmer, Industrial Archaeology: Principles and Practice (London, Routledge, 1998), p. 99.

19. Kevin Walsh, The Representation of the Past: Museums and Heritage in the Post-Modern World (London, Routledge, 1992), p. 135.

20. Michael E. Rose, Keith Falconer and Julian Holder, Ancoats: Cradle of Industrialisation (Swindon, English Heritage, 2011), p.1.

21. Mike Williams, 'The Mills of Ancoats”, Manchester Region History Review, vol. 7 (1993), p. 32 .

22. Mark Crinson, Paul Tyrer, "Clocking off in Ancoats: time and remembrance in the post-industrial city", in Mark Crinson (ed.), Urban Memory: History and Amnesia in the Modern City (London, Routledge, 2005), p. 50.

23. Ancoats - the World's First Industrial Suburb, op. cit.

24. Steve Little, op. cit., p. 97.

25. Supplementary Planning Guidance - Ancoats Urban Village (Manchester, Manchester City Council, 1999), p. 5.

26. One of their aims was to catalyse the regeneration of deindustrialised urban areas. See Rebecca Madgin, "Making the most of our existing urban assets? New Labour's focus on the historic urban environment", in Sylvie Nail and David Fee (eds.), Vers une renaissance anglaise: dix ans de politique travailliste de la ville (Paris, Presses Sorbonne Nouvelle, 2008), p. 39.

27. Listed buildings are protected by planning controls and consent is therefore required for alterations or demolitions as these might affect their special architectural or historic interest.

28. World Heritage UK, <https://worldheritageuk.org/category/conference-saltaireoctober-2015/>, [accessed 28 January 2019].

29. Saltaire, UNESCO World Heritage Centre Nomination Documentation, p. 269.

30. Mike Priestley, « Saltaire », Telegraph and Argus, 24 March 1990. 
31. This organisation has been campaigning for the protection of the historic environment since its creation in 1975, John Pendlebury, "Conservation of the historic environment", p. 326.

32. Kenneth Powell, "Mill into Museum”, The Daily Telegraph, July 1987.

33. Kathy Myers, "End of a 133 Year Era at Salts Mill”, Telegraph and Argus, 10 August 1986.

34. Bradford Historical and Antiquarian Society, "Crisis at Saltaire", 1987, [accessed 5 May 2019]. <http://www.bradfordhistorical.org.uk/saltaire.html>

35. Marcus Binney, Kenneth Powell and Derek Linstrum, Crisis at Saltaire: What Future for Titus Salt's Mill? (London, SAVE Britain's Heritage, 1986).

36. Kenneth Powell, "Phenomenal Monument at Risk: Crisis at Saltaire", Country Life (20 March 1986), p. 714

37. Clive Woods, "Emergency Seminar for Saltaire: Experts Fight to Save Mill”, Target, n 290 (3 April 1986).

38. One of the proposals was to relocate Bradford's Industrial Museum (Moorside Mill) in Salts Mill, as the latter was listed and was also bigger.

39. Bradford Historical and Antiquarian Society, "Crisis at Saltaire", op. cit.

40. Kenneth Powell, "Mill into Museum", op. cit.

41. Kevin Walsh, op. cit., p. 139.

42. Ibid., p.100.

43. Helen Thornton, "Saltaire's Role in Regeneration", 21 July 2014, <https:// www.academyofurbanism.org.uk/saltaires-role-in-regeneration/>, [accessed 13 October 2018].

44. Mike Priestley, "Saltaire", Telegraph and Argus, 24 March 1990.

45. Hilary Macaskill, "Local Hero, Local Colour”, The Guardian, Thursday 15 February 1996.

46. Saving the Age of Industry, Conservation Bulletin, English Heritage, $\mathrm{n}^{\circ} 67$ (autumn 2011).

47. Eleanor Casella and James Symonds (eds.), Industrial Archaeology: Future Directions (New York, Springer Science \& Business Media, 2005), p.167.

48. Jim Greenhalf, "How The Arts Can Give City a Kick up the Pants", Telegraph and Argus, undated.

49. European Route of Industrial Heritage, <http://www.erih.net/i-want-to-go-there/site/show/ saltaire-village/>, [24 October 2016].

50. Idem.

51. Robert Willims, "Looking with new eyes at the old factory: on the rise of industrial cool", in Tom O'Dell and Peter Billing, Experiencescapes: Tourism, Culture and Economy (Copenhagen, Copenhagen Business School Press DK, 2005), p. 42.

52. Richard Rayner, "Mills and Boom”, Telegraph Weekend Magazine, 16 September 1989.

53. Jim Greenhalf, "Salt of the Arts: Two Top Yorkshire Artists Bring Exclusive Works to Bradford", Telegraph and Argus, Friday 16 July 1993.

54. This expression is probably a play on words, since "Mills and Boon" is a British company that publishes romance and fiction books.

55. Marcus Binney, Ron Fitzgerald, Randolph Langenbach and Kenneth Powell, Satanic Mills: Industrial Architecture in the Pennines (London, SAVE Britain's Heritage, 1978).

56. Roger Clark, "A Look into the Past: Why Saltaire Is on a Par with the Pyramids", Prosider Guide, Shipley, Saltaire (Bradford, Prosider Media Publishing, 2008), p. 24.

57. "Hockney Unveils Tribute to Mill Owner and Friend", Yorkshire Post, 15 December 1997.

58. When Express Printers closed down in 1989, the retail sector in the vicinity was impacted by the departure of the firm's employees, and Ancoats started dying, Michael E. Rose, Keith Falconer and Julian Holder, Ancoats: Cradle of Industrialisation, p. 67.

59. Daily Express Building, A-Z of Listed Buildings in Manchester, <http:// www.manchester.gov.uk/info/514/listed_buildings_register/1908/a-

z_of_listed_buildings_in_manchester/7>, [accessed 6 December 2018]. 
60. Lyn Fenton, interview by the author, 3 October 2016, Manchester.

61. Deborah Haile, "Ancoats Hailed as 'New Castlefield", Manchester Evening News, 28 October 1999.

62. Jane Lavender, "More than Cotton Mills and Canals", Metro magazine, 15 August 2003.

63. Ancoats Urban Village, Annual Report, North West Development Agency, 2007.

64. Heritage Lottery Fund, "HLF Major Grants - The first 100", June 2015, < https:// www.heritagefund.org.uk/sites/default/files/media/research/hlf_major_grants__the_first_100.pdf >, [accessed 23 March 2019].

65. Andrew Tallon, Urban Regeneration in the UK (Abingdon, Routledge, [2010], 2013), p. 5.

66. The succession of mills by the Rochdale canal was included in the bid, Robina McNeil, David George (eds.), Manchester - Archetype City of the Industrial Revolution: A Proposed World Heritage Site (Manchester, University of Manchester Field Archaeology Centre, 2002), p. 13.

67. Michael E. Rose et al., op. cit., p. 82.

68. Liverpool City Council and UNESCO clashed over the Liverpool Waters regeneration scheme as it could affect the character of the historic waterfront which received World Heritage status in 2004, Denis Rodwell, "Heritage and development - Bridging the gap?", in Heike Oeverman and Harald A. Mieg (eds.), Industrial Heritage Sites in Transformation: Clash of Discourses (New York, Routledge, 2015), p. 29.

69. It was set up in 1996, Ancoats Annual Review, North West Development Agency, 2008-2009, p. 4.

70. Lyn Fenton, interview by the author, 3 October 2016, Manchester.

71. Ancoats Annual Review, North West Development Agency, 2008-2009.

72. Ibid., p.5.

73. Rosemary Mellor, "Cool times for a changing city", in Nick Jewson and Susanne Macgregor (eds.), Transforming Cities: Contested Governance and New Spatial Divisions (London, Routledge, 1997), p. 57.

74. Supplementary Planning Guidance - Ancoats Urban Village, foreword.

75. Ancoats Urban Village Heritage Lottery funding bid.

76. Regeneration Prospectus: To Further Economic Development and Regeneration, North West Development Agency, March 2002, p. 29.

77. Ancoats Annual Review, North West Development Agency, 2009-2010.

78. Ancoats Peeps, <http://ancoatspeeps.com/?p=cultural-masterplanning>, [accessed 18 October 2018].

79. Michael E. Rose et al., op. cit., p. 93-94.

80. New Labour started using the expression "creative industries" instead of "cultural industries" to refer to industries based on creativity, skill and talent which can create jobs and wealth. It is an umbrella term for diverse sectors such as cinema, television, video games, radio, music, art, architecture, design, fashion, tourism, etc., Graeme Evans and Phyllida Shaw, op. cit., p. 4.

81. Paul Butler, Ian Finlay, David Tye, "Ancoats Urban Village: old mills, new homes", in John Parkinson-Bailey (ed.), Sites of the City, Manchester: Essays on Recent Buildings by their Architects (Manchester, Manchester Metropolitan University, 1996), p. 118.

82. Heritage Works, <http://www.heritageworks.co.uk/abpt-final/ about_ancoats_buildings.htm>, [accessed 24 October 2018].

83. MCR 5, MCR Magazine, 6 May 2010, p. 32.

84. Kevin Lynch, What Time Is This Place? (Cambridge, Massachusetts, the M.I.T. Press, [1972] 2001), p. 13.

85. Ancoats - History with a Future, Ancoats Buildings Preservation Trust, Manchester Central Library: Special Collections, GB127.MISC/1281/2/2/2 
86. Octave Debary, "Deindustrialisation and museumification: from exhibited memory to forgotten history", Annals of the American Academy of Political and Social Science vol. 595 (2004), p. 122.

87. Annual Report 1993, p. 4.

88. Ancoats - An Archaeological Perspective, Oxford Archaeology North, Ancoats Buildings Preservation Trust, Manchester Central Library: Special Collections, GB127.MISC/1281/2/2/5

89. Supplementary Planning Guidance - Ancoats Urban Village, p. 6.

90. Casella, Industrial Archaeology: Future Directions, p. xi.

91. Visit Manchester is a division of Marketing Manchester, an agency which promotes the city both nationally and internationally.

92. Visit Manchester Brief: Public Relations for Modern History, Visit Manchester, September 2010, p. 4, <http://www.marketingmanchester.com/media/31071/brief\%20for\%20pr.doc.>, [accessed 2 May 2019].

93. Top 5 Industrial Heritage Attractions, Visit Manchester, <www.visitmanchester.com/articles/ top-5s/top-5-industrial-heritage-attractions/>, [accessed 25 January 2016].

94. Best of Top 5, Visit Manchester, <www.visitmanchester.com/articles/top-5s/best-of-top-5s/>, [accessed 25 January 2019].

95. What to Do, Visit Manchester, <www.visitmanchester.com/what-to-do/>, [accessed 25 January 2019].

96. "Industrial Powerhouse", MCR Magazine, November 2008, p. 80.

97. Visit Manchester Brief: Public Relations for Modern History, p. 5.

98. “Industrial Heritage”, MCR Magazine, November 2008, pp. 78-79.

99. MCR 5, MCR Magazine, p. 49.

100. John R. Gold, "Locating the message: place promotion as image communication", in John R. Gold and Stephen V. Ward (eds.), Place Promotion: The Use of Publicity and Marketing to Sell Towns and Regions (Chichester, Wiley, 1994), p. 22.

101. John Heeley, Urban Destination Marketing in Contemporary Europe: Uniting Theory and Practice, Bristol: Channel View Publications, 2015, p. xvii.

102. Bradford Industrial Heritage Tour, 1982; Bradford's Yorkshire Heritage Breaks September 1982-April 1983; Bradford's Brontë Country Mini-Holidays, January-December 1984, Bradford Economic Development Unit, City of Bradford Metropolitan Council, 1984.

103. Maria Glot, interview by the author, 13 October 2016, Saltaire.

104. Conference Guide Bradford and District, Department of Marketing and Communications, City of Bradford Metropolitan District Council, 2001, Shipley College: The Saltaire Collection Archive.

105. Bradford and District Visitor Guide 2016, Visit Bradford, City of Bradford Metropolitan District Council, 2016.

106. Elizabeth Auclair and Graham Fairclough (eds.), op. cit., p. 4.

\section{ABSTRACTS}

$\mathrm{T}$

he promotion of heritage and culture-led regeneration in Ancoats and Saltaire, two formerly industrial districts of Manchester and Bradford, are comparatively examined in this article. 
It seeks to analyse the

role of industrial heritage amidst initiatives aiming at the regeneration and reuse of the historic built environment, in a context suggesting a positive reassessment of industrial vestiges in the North of England. If both northern post-industrial cities are determined to improve their image and to promote themselves as tourist destinations, they strongly differ with regard to the use of industrial heritage as a promotional tool, thereby implying a swaying between the acknowledgment of the industrial past and the will to move forward.

Cet article propose une étude comparative de la promotion de la régénération par le patrimoine et la culture à Ancoats et Saltaire, deux zones anciennement industrielles de Manchester et de Bradford. Il s'agit d'analyser le rôle du patrimoine industriel en relation avec des initiatives qui visent la régénération et le réemploi du bâti historique, dans un contexte suggérant une réévaluation positive des vestiges industriels dans le Nord de l'Angleterre. Si ces villes postindustrielles sont toutes deux déterminées à améliorer leur image et à s'auto-promouvoir en tant que destinations touristiques, elles diffèrent considérablement en ce qui concerne l'utilisation du patrimoine industriel comme outil promotionnel, laissant ainsi deviner une oscillation entre la reconnaissance du passé industriel et la volonté d'aller de l'avant.

INDEX

Mots-clés: Nord de l'Angleterre, patrimoine, industriel, régénération, promotion

Keywords: Northern England, industrial, heritage, regeneration, promotion

\section{AUTHOR}

AURORE CAIGNET

ACE, EA 1796, Université Rennes 2 